\title{
Impact of Organic Manure on Growth, Nutrient Content and Yield of Chilli Pepper under Various Temperature Environments
}

\author{
Botir Khaitov ${ }^{1}{ }^{1}$, Hye Jin Yun ${ }^{1}$, Yejin Lee ${ }^{2}$, Farrukh Ruziev ${ }^{1}$, Thi Hien Le ${ }^{1}$, \\ Mirjalol Umurzokov ${ }^{1}$, Aung Bo Bo ${ }^{1}$, Kwang Min Cho ${ }^{1}$ and Kee Woong Park ${ }^{1, *}$ \\ 1 Crop Science Department, Chungnam National University, Daejeon 34134, Korea \\ 2 Soil Management Division, NIAST, Rural Development Agency, Wanju 55365, Korea \\ * Correspondence: parkkw@cnu.ac.kr; Tel.: +82-42-821-7823
}

Received: 18 June 2019; Accepted: 17 August 2019; Published: 21 August 2019

\begin{abstract}
Expected climatic changes likely elicit serious challenges for crop production. Therefore, it is indispensable to investigate the response of crop growth parameters and yield under temperature variability environments. The current experiment on chilli pepper growth was conducted in a field, rain-shelter plastic house, and plastic greenhouse, with accumulated temperatures of $2832{ }^{\circ} \mathrm{C}, 2967^{\circ} \mathrm{C}$, and $3105^{\circ} \mathrm{C}$ in 2017; and $2944^{\circ} \mathrm{C}, 3091{ }^{\circ} \mathrm{C}$, and $3168^{\circ} \mathrm{C}$ in 2018 growing seasons. Based on soil analysis, $132.7 \mathrm{~kg} \mathrm{ha}^{-1}$ (1× of livestock manure compost as an optimum and $265.4 \mathrm{~kg} \mathrm{ha}^{-1}(2 \times)$ as a double amount of organic matter were applied to each simulated temperature condition. The results showed that organic manure application favorably affects the growth attributes and nutrient uptake of chilli pepper with the highest values found in the plastic greenhouse, followed by the rain-shelter house, over the open field cultivation condition. The highest growth of chilli pepper was at the $2 \times$ rate of organic manure application, whereas the highest yield was found at the $1 \times$ rate of organic manure application. The application of organic manure at the $1 \times$ rate in the greenhouse increased root, shoot, and fruit dry weights of chilli pepper by $21.4 \%, 52.4 \%$, and $79.7 \%$, respectively, compared to the control values. These results indicate that the rational use of organic amendments might be the best solution for chilli pepper production under variable climate conditions.
\end{abstract}

Keywords: chilli pepper; organic manure; application rate; elevated temperature; rain-shelter plastic house; greenhouse; field

\section{Introduction}

Global warming poses a great threat to crop production all around the world. The increase in atmospheric temperature in response to global climate change might have serious consequences for crop production and be dangerous for food security [1]. Furthermore, continuously increasing populations in the world put pressure on agriculture to produce more crops. The consequences of climate change on crop production, cropping system, and soil fertility are expected to be huge but uncertain [2]. According to scientific predictions, climate change will be responsible for increase in temperature and precipitation up to $1.0-5.0^{\circ} \mathrm{C}$ and $9-11 \%$, respectively, depending on regions by the end of this century [3]. This will very likely bring a negative impact to crop production [4,5]. While, simultaneous rise in atmospheric $\mathrm{CO}_{2}$ and temperature are already showing some impact on nature, in the meantime, it is prudent to study the performance of crop species under simulated high temperature conditions.

The effectiveness of organic amendments is also theorized to change along with climate change [6]. Application of organic manure increases organic elements' availability in soil, thereby improving 
the nutrient use efficiency (NUE) of crops and alleviating the harmful impact of climate change on crop production [7]. However, the application rate of chemical fertilizers has soared extensively during the last decades to enhance crop yield in order to meet the increasing demand of populations. The consequences are already visible on serious ecological disturbances, especially in pollution of soil and water resources. In recent years, the scientific community has been informing the advantages of implementing organic farming in agricultural production to ensure sustainable nutrient management for crops, food safety, and soil health [8]. This strategy improves NUE, while maintaining high productivity of crops, soil quality, and agricultural sustainability.

Soil is one of the most important environmental factors with indispensable significance in plant physiology [9]. Thus, maintaining soil quality is of great importance for crop growth and enhancing productivity. Organic manure is a natural source of nitrogen $(\mathrm{N})$ formation process in the soil. Livestock manure returns essential macroelements including $\mathrm{N}(2.42 \%), \mathrm{P}(1.51 \%)$, and $\mathrm{K}(0.41 \%)$, as well as micronutrients such as magnesium, calcium, sulfur, and manganese to the soil while maintaining its fertility. Several researchers have reported that nutrients available for plant uptake increase rapidly in the experimental soil after organic manure application, although bacterial populations were different in various soils $[10,11]$. Microorganisms living in the soil are important for decomposing, mineralizing, and recycling organic matters [12]. Microbial populations intensively induce the production of phytohormones such as gibberellin and auxin in plant roots grown in fertile soil with rich organic manures which stimulate plant growth [13].

Chilli pepper (Capsicum annuum), the most known species of the plant genus Capsicum (peppers), originated in Mexico, the southern part of North America. Nowadays, this crop is commonly cultivated in all continents of the world and mainly used for food and pharmaceutical uses. Superior levels of bioactive and antioxidant compounds such as carotenoids, phenolic compounds, and ascorbic acid are contained in fresh chilli pepper fruits [14]. However, the level of these components in the fruit depends on genetic and environmental factors. If chilli pepper is grown for a food ingredient, its quality and market value are determined by the level of fruit pungency [15]. Some essential components are enhanced in organically cultivated crops, for instance, quercetin (flavonoid) in spinach, Chinese cabbage, and Welsh onion [16]; phenol and flavonoid in Labisia pumila [17]; protein and carotene in Capsicum chinense [18]; and capsaicin content in pepper [11].

In Korea, the cultivation area of chili peppers is $\sim 30$ thousand hectares, and the fruit production reached $\sim 72$ thousand tones in 2018, increasing by 16 thousand tones (28.4\%) from 56 thousand tones in 2017 [19]. It is well-known that climate change causes modifications in crop physiology, NUE efficacy, yield, and other parameters [20]. Therefore, it is important to elucidate the impact of climate change on crop productivity for sustainable agricultural production.

Our goal in this study was to evaluate the effect of $1 \times$ rate $\left(132.7 \mathrm{~kg} \mathrm{ha}^{-1}\right)$ and $2 \times$ rate $\left(265.4 \mathrm{~kg} \mathrm{ha}^{-1}\right)$ livestock manure treatments compared to control (without manure) on the growth and yield parameters of chilli peppers grown under three different environmental conditions such as a plastic greenhouse, rain-shelter plastic house, and open field conditions. The objective of this research was to study how chilli peppers react to the different rates of organic manure application under expected climate change scenarios. Furthermore, we were curious to understand how plant physiology parameters such as chlorophyll content, plant height, shoot, and root dry weights change in response to the applied organic manure under various temperature environments.

\section{Material and Methods}

\subsection{Experimental Conditions and Plant Material}

The climate of South Korea with four seasons allows the cultivation of many crop species. The average annual air temperature ranges between $-5{ }^{\circ} \mathrm{C}$ to $-2.5^{\circ} \mathrm{C}$ in January and $22.5^{\circ} \mathrm{C}$ to $25^{\circ} \mathrm{C}$ in July. The annual precipitation is $\sim 1380-1400 \mathrm{~mm}$, the main part of it falls between November and May, with an average humidity of $66 \%$. 
A two-year experiment, during 2017 and 2018 growing seasons, was conducted in the field, rain-shelter plastic house, and plastic greenhouse conditions simulating three different temperature environments. Climate parameters in the plastic greenhouse and rain-shelter plastic house were recorded with an Em50 ${ }^{\circledR}$ series data logger (METER Group, Inc., Pullman, WA, USA). During the growing seasons, the highest air temperature was observed in the greenhouse, followed by rain-shelter plastic house compared to the field. However, the highest amount of rainfall precipitated in the field experiment. The accumulated temperatures for 130 days were $2832^{\circ} \mathrm{C}, 2967{ }^{\circ} \mathrm{C}$, and $3105^{\circ} \mathrm{C}$ in 2017 ; and $2944^{\circ} \mathrm{C}, 3091^{\circ} \mathrm{C}$, and $3168^{\circ} \mathrm{C}$ in 2018 in plastic greenhouse, rain-shelter plastic house, and open field conditions, respectively. The detail climatic records for both growing season are presented in Table 1.

Table 1. Weather data on air temperature, rainfall, and relative humidity of the study area, Chungnam province (2017 to 2018 growing seasons' data).

\begin{tabular}{|c|c|c|c|c|c|c|}
\hline \multirow{2}{*}{ Year } & \multicolumn{6}{|c|}{ Month of the Year } \\
\hline & May & Jun. & Jul. & Aug. & Sep. & Oct. \\
\hline & \multicolumn{6}{|c|}{ Air Temperature $\left({ }^{\circ} \mathrm{C}\right)$} \\
\hline 2017 Field & 22.2 & 26.4 & 24.6 & 24.9 & 19.5 & 13.3 \\
\hline Rain-shelter house & 22.4 & 23.7 & 27.8 & 26.7 & 21.8 & 14.1 \\
\hline Greenhouse & 23.3 & 24.6 & 28.3 & 27.1 & 22.4 & 14.8 \\
\hline 2018 Field & 18.8 & 20.8 & 25.1 & 25.1 & 18.5 & 12 \\
\hline Rain-shelter house & 19.3 & 21.6 & 26.6 & 26.4 & 19.5 & 13.1 \\
\hline \multirow[t]{2}{*}{ Greenhouse } & 20.1 & 22.4 & 27.3 & 26.7 & 19.7 & 13.9 \\
\hline & \multicolumn{6}{|c|}{ Rainfall (mm) } \\
\hline 2017 & 35.8 & 51.4 & 326.7 & 358.4 & 97.1 & 51.9 \\
\hline \multirow[t]{2}{*}{2018} & 90.4 & 225.5 & 100 & 437.1 & 91.3 & 90.2 \\
\hline & \multicolumn{6}{|c|}{ Relative Humidity (\%) } \\
\hline 2017 Field & 93.4 & 94.5 & 94.9 & 95.1 & 95.6 & 95.7 \\
\hline Rain-shelter house & 92.9 & 93.6 & 93.8 & 93.9 & 94 & 94.2 \\
\hline Greenhouse & 94 & 94.1 & 94.6 & 94.7 & 95.1 & 95.2 \\
\hline 2018 Field & 95.8 & 95.7 & 95.8 & 95.7 & 96.1 & 96.5 \\
\hline Rain-shelter house & 94.7 & 94.5 & 94.6 & 94.5 & 94.9 & 95.3 \\
\hline \multirow[t]{2}{*}{ Greenhouse } & 95.1 & 94.9 & 95.1 & 95 & 95.4 & 95.8 \\
\hline & \multicolumn{6}{|c|}{ Soil Moisture } \\
\hline 2017 Field & 0.28 & 0.242 & 0.221 & 0.234 & 0.231 & 0.224 \\
\hline Rain-shelter house & 0.231 & 0.179 & 0.166 & 0.181 & 0.174 & 0.166 \\
\hline Greenhouse & 0.187 & 0.193 & 0.185 & 0.171 & 0.185 & 0.201 \\
\hline 2018 Field & 0.26 & 0.264 & 0.28 & 0.278 & 0.279 & 0.285 \\
\hline Rain-shelter house & 0.201 & 0.174 & 0.18 & 0.201 & 0.196 & 0.193 \\
\hline Greenhouse & 0.249 & 0.229 & 0.218 & 0.233 & 0.221 & 0.217 \\
\hline
\end{tabular}

Source: Meteorological Station of Chungnam province, Korea.

Seeds of chilli pepper (Capsicum annuum L.) variety-Keunsarang (Nongwoo Bio, Sunwon, Korea) - were obtained from Crop Physiology department, Chungnam National University, Korea. Prior to starting the experiment, the seeds were sorted: broken seeds were discarded and good quality seeds were chosen for further use in the experiment. The seeds' surface was sterilized with a $0.2 \%$ $\mathrm{Hg}_{2} \mathrm{Cl}$ solution for $3 \mathrm{~min}$, rinsed in distilled water thoroughly, and left to dry at room temperature (25 ${ }^{\circ} \mathrm{C}$ ). Then, the seeds were sown directly into $2 \mathrm{~cm}$ depth soil in pots (30 $\mathrm{cm}$ in diameter). Each pot was filled with $4 \mathrm{~kg}$ of soil (55\% clay, 20\% silt, and 25\% sand) and the experiment was commenced in the greenhouse of Crop Physiology Department, Chungnam National University. The seeds germinate under favorable environmental conditions in the 2nd week of April each year (day length 15-16 h, temperature $25-30{ }^{\circ} \mathrm{C}$, and humidity $65-70 \%$ ). When the germination was complete after 7 days, the 
percentage of seed germination was calculated and the seedling density was thinned to four seedlings per pot.

The seedlings of chilli pepper were transplanted into a plastic greenhouse, rain-shelter plastic house, and open field at the experimental station located in Unbong-eup, Namwon-si, Jeollabuk-do, Republic of Korea. The experiment was set in randomized complete block design with three replicated plots $(15 \mathrm{~m} \times 4 \mathrm{~m})$ for each treatment.

The chemical analyses of organic manure were conducted to estimate $\mathrm{N}, \mathrm{P}_{2} \mathrm{O}_{5}$, and $\mathrm{K}_{2} \mathrm{O}$ contents before application. The organic manure consisted of $67.06 \%$ organic matter, $2.42 \% \mathrm{~N}, 1.51 \% \mathrm{P}_{2} \mathrm{O}_{5}$, and $0.41 \% \mathrm{~K}_{2} \mathrm{O}$. Two different levels of organic matter were applied to each temperature treatments as per experimental layout. Based on a soil analysis, $132.7 \mathrm{~kg} \mathrm{ha}^{-1}(1 \times)$ of livestock manure compost as an optimum and $265.4 \mathrm{~kg} \mathrm{ha}^{-1}(2 \times)$ was applied as the double rate of organic manure.

Ammonium nitrate (34\%), fused phosphate (17\%), and muriate of potash $(52 \%)$ were applied as inorganic sources of N, P, and K. Recommended doses of the chemical fertilizers N, P $\left(\mathrm{P}_{2} \mathrm{O}_{5}\right)$, and $\mathrm{K}\left(\mathrm{K}_{2} \mathrm{O}\right)$ were $80: 50: 40 \mathrm{~kg} \mathrm{ha}^{-1}$, and this amount was divided into three equal portions. The first part was applied as a basal dose and the two remaining portions were given during the vegetation period. All other agronomic operations such as plant protection, weeding, and irrigation measures were conducted similarly in all plots.

\subsection{Soil Analyses}

The soil in the experimental area belongs to Podzolic (ash-gray forest soil), slightly acidic with pH 5.9-6.6 and EC 1.3-2.4 dS/m. It consists of clay 540-585 $\mathrm{g} \mathrm{kg}^{-1}$, silt 260-291 g kg-1, organic matter $18.7-25.7 \mathrm{~g} \mathrm{~kg}^{-1}$, and sand $150-172 \mathrm{~g} \mathrm{~kg}^{-1}$. Soil chemical analyses indicated that $\mathrm{NO}_{3}-\mathrm{N}, 52.9 \mathrm{mg} / \mathrm{kg}$; $\mathrm{NH}_{4}{ }^{+}-\mathrm{N}, 13.2 \mathrm{mg} / \mathrm{kg} ; \mathrm{P}_{2} \mathrm{O}_{5}, 671.4 \mathrm{mg} / \mathrm{kg} ; \mathrm{K}, 1.2 \mathrm{cmol} / \mathrm{kg} ; \mathrm{Ca}, 8.5 \mathrm{cmol} / \mathrm{kg} ; \mathrm{Mg}, 2.6 \mathrm{cmol} / \mathrm{kg}$; and Na, $0.3 \mathrm{cmol} / \mathrm{kg}$.

Soil samples were randomly collected at $0-30 \mathrm{~cm}$ depth in sealable plastic bags from each replicated plot every month during the experiment. Air-dried soil samples at room temperature were ground and sieved through a 2-mm mesh before chemical analysis.

Soil and plant samples were analyzed according to the methods developed by the National Institute of Agricultural Science and Technology (NIAST, 2000). Soil $\mathrm{pH}$ and EC parameters were measured with $\mathrm{pH}$ and EC meters using $1: 5$ ratio of soil and distilled water. The organic matter was extracted using the Tyurin method, available phosphate was extracted using the Lancaster method [21], and substitutional cation was extracted using $1 \mathrm{M} \mathrm{NH}_{4} \mathrm{OAC}(\mathrm{pH}$ 7.0) and analyzed with a coupled plasma spectrophotometer (Integra XL, GBC, Toronto, Canada).

Plant materials were dried and pulverized, and then $1 \mathrm{~mL}$ of concentrated sulfuric acid and $10 \mathrm{~mL}$ of $50 \%$ perchloric acid were added into $0.5 \mathrm{~g}$ of the sample, followed by decomposition by heating on a hot plate. Total $\mathrm{N}, \mathrm{P}_{2} \mathrm{O}_{5}$, and $\mathrm{K}_{2} \mathrm{O}$ were analyzed with Kjeldahl distillation, Vanadate method, and inductively coupled plasma spectrophotometer, respectively [22]. Furthermore, the ECH2O 5TE Sensor (Decagon devices, Pullman, WA, USA) was deployed for temperature and moisture analyses. Ambient temperature, humidity, and radiation were determined by ATMOS14 (Decagon devices, USA).

\subsection{Plant Sampling, Fruit Yield, and Yield Attributing Features of Chilli Peppers}

Investigations of plant growth parameters were conducted at 30, 50, 70, 100, and 130 days after transplanting (DAT). Harvesting chilli fruits began two weeks after the beginning of the mature stage, around 95 DAT.

The parameters of plant height, dry weight of shoot and root, length of internode, chlorophyll contents of leaf, stem diameter, and number of fruit branches were measured in three replicates. The chilli pepper fruit was harvested every two weeks from each treatment. The number of fruits, fruit weight, and color were recorded until the final harvest. Fruit samples were stored in a $-4{ }^{\circ} \mathrm{C}$ refrigerator until used for further chemical analyses. Fruit quality attributing parameters, including 
crude protein and total $\mathrm{N}$, were determined by the modified Kjeldahl method [23]. The yield was calculated by estimating the number of fruits harvested for 130 days.

\subsection{Statistical Analysis}

The effects of organic manure application on growth attributes, nutrient content, and chilli pepper yield were determined under three different temperature conditions in two growing seasons (2017 and 2018), and were subjected to statistical significance using the ANOVA CROPSTAT program. No significant differences in any traits were observed between the two experimental years, and data was pooled before statistical analysis. Student's t-test was used for comparative analyses between treatments. The mean comparisons were conducted using a least significant difference (LSD) test $(p \leq 0.05)$.

\section{Results}

\subsection{Effects of Organic Manure and Temperature Increase on the Growth of Chilli Peppers}

The application of organic manure had a significant positive effect on plant growth parameters such as plant height, length of internode, number of fruit branches, and stem diameter, and the effect was more pronounced under elevated temperature conditions (Tables 2 and 3). Organic manure treated at the $2 \times$ rate yielded the highest plant growth (plant height, length of internode, number of fruit branches, and stem diameter), was and was substantially higher than those of the $1 \times$ rate treatment at all temperature environments. Although a significant difference was not detected, the chlorophyll content of leaf and stem diameter parameters increased with application rate increase. However, compared to the field condition plant growth parameters such as plant height, stem diameter, dry weight of shoot and root, and number of fruit branches tended to be significantly higher under the greenhouse followed by rain-shelter house conditions. The application of organic manure at the $1 \times$ rate increased plant height and the number of fruit branch parameters by $28.9 \%$ and $37.8 \%$ in the greenhouse and by $23.3 \%$ and $26.1 \%$ in the rain-shelter house, respectively, compared to the field. Likewise, when organic manure was applied at the $1 \times$ rate, the length of internode increased by $44.7 \%$ and $34.3 \%$ in the greenhouse and rain-shelter house, respectively, compared to the field values (Table 2).

Table 2. Plant growth attributes at 70 DAT.

\begin{tabular}{|c|c|c|c|c|c|c|}
\hline Main Plot & Treatments & Height (cm) & Chlorophyll & $\begin{array}{c}\text { Length of } \\
\text { Internode }(\mathrm{cm})\end{array}$ & $\begin{array}{c}\text { Stem Diameter } \\
(\mathrm{mm})\end{array}$ & $\begin{array}{c}\text { Fruit Branch } \\
\text { (No.) }\end{array}$ \\
\hline \multirow{3}{*}{ Field } & control & $86.7 \mathrm{~g}$ & $62.6 \mathrm{a}$ & $6.0 \mathrm{~d}$ & $9.0 \mathrm{a}$ & $22.3 \mathrm{~cd}$ \\
\hline & $\mathrm{X} 1$ & $89.0 \mathrm{~g}$ & $65.1 \mathrm{a}$ & $6.7 \mathrm{~cd}$ & $9.6 \mathrm{a}$ & $23.0 \mathrm{~cd}$ \\
\hline & $\mathrm{X} 2$ & $92.0 \mathrm{fg}$ & $68.7 \mathrm{a}$ & $8.0 \mathrm{~cd}$ & $11.1 \mathrm{a}$ & $21.0 \mathrm{~d}$ \\
\hline \multirow{3}{*}{$\begin{array}{l}\text { Rain-shelter } \\
\text { house }\end{array}$} & control & $106.0 \mathrm{de}$ & $66.1 \mathrm{a}$ & $8.3 \mathrm{~cd}$ & $9.1 \mathrm{a}$ & $26.3 \mathrm{~cd}$ \\
\hline & X1 & $109.7 \mathrm{~cd}$ & $64.6 \mathrm{a}$ & $9.0 \mathrm{bc}$ & $9.9 \mathrm{a}$ & $29.0 \mathrm{bc}$ \\
\hline & $\mathrm{X} 2$ & $116.7 \mathrm{ab}$ & $67.5 \mathrm{a}$ & $9.8 \mathrm{ab}$ & $10.3 \mathrm{a}$ & $24.7 \mathrm{~cd}$ \\
\hline \multirow{3}{*}{ Green house } & control & $111.0 \mathrm{bc}$ & $62.3 \mathrm{a}$ & $7.7 \mathrm{~cd}$ & $10.2 \mathrm{a}$ & $31.7 \mathrm{ab}$ \\
\hline & X1 & $114.7 \mathrm{bc}$ & $62.3 \mathrm{a}$ & $9.7 \mathrm{ab}$ & $11.0 \mathrm{a}$ & $31.7 \mathrm{ab}$ \\
\hline & $\mathrm{X} 2$ & $122.7 \mathrm{a}$ & $65.0 \mathrm{a}$ & $10.7 \mathrm{a}$ & $11.6 \mathrm{a}$ & $38.0 \mathrm{a}$ \\
\hline LSD 0.05 & & 14.4 & 6.99 & 2.16 & 3.93 & 7.72 \\
\hline CV (\%) & & 8.2 & 6.2 & 8.1 & 11.6 & 6.4 \\
\hline
\end{tabular}

Means separated by same lower case letter in each column are not significantly different at $p<0.05$ among treatments. LSD = least significant difference.

Table 3. Dry weights of root, shoot, leaf, and fruits at 70 DAT.

\begin{tabular}{lccccc}
\hline Main Plot & Treatments & Root $(\mathrm{g})$ & Shoot $(\mathrm{g})$ & Leaf $(\mathrm{g})$ & Fruit $(\mathrm{g})$ \\
\hline \multirow{3}{*}{ Field } & control & $3.7 \mathrm{~g}$ & $21.6 \mathrm{~g}$ & $21.6 \mathrm{e}$ & $67.4 \mathrm{~g}$ \\
& $\mathrm{X} 1$ & $4.5 \mathrm{~cd}$ & $27.6 \mathrm{ef}$ & $25.2 \mathrm{e}$ & $83.8 \mathrm{de}$ \\
& $\mathrm{X} 2$ & $4.3 \mathrm{de}$ & $23.9 \mathrm{~g}$ & $22.2 \mathrm{e}$ & $77.9 \mathrm{ef}$ \\
\hline
\end{tabular}


Table 3. Cont.

\begin{tabular}{lccccc}
\hline Main Plot & Treatments & Root $(\mathrm{g})$ & Shoot $(\mathrm{g})$ & Leaf $(\mathrm{g})$ & Fruit $(\mathrm{g})$ \\
\hline \multirow{2}{*}{ Rain-shelter } & control & $4.0 \mathrm{f}$ & $31.0 \mathrm{ef}$ & $26.4 \mathrm{de}$ & $72.3 \mathrm{fg}$ \\
house & X1 & $4.6 \mathrm{bc}$ & $37.8 \mathrm{bc}$ & $33.0 \mathrm{bc}$ & $95.7 \mathrm{~b}$ \\
& X2 & $4.7 \mathrm{ab}$ & $37.5 \mathrm{~cd}$ & $34.7 \mathrm{ab}$ & $87.2 \mathrm{~cd}$ \\
\hline \multirow{3}{*}{ Green house } & control & $4.2 \mathrm{ef}$ & $34.6 \mathrm{de}$ & $23.8 \mathrm{de}$ & $85.7 \mathrm{de}$ \\
& X1 & $4.7 \mathrm{ab}$ & $37.9 \mathrm{ab}$ & $31.0 \mathrm{~cd}$ & $114.6 \mathrm{a}$ \\
& X2 & $4.9 \mathrm{a}$ & $41.8 \mathrm{a}$ & $35.1 \mathrm{a}$ & $92.6 \mathrm{bc}$ \\
\hline & LSD 0.05 & 2.83 & 6.45 & 5.46 & 10.47 \\
& CV (\%) & 11.0 & 13.5 & 13.1 & 8.3
\end{tabular}

Means separated by same lower case letter in each column are not significantly different at $p<0.05$ among treatments. LSD = least significant difference.

Similarly, the observation conducted in 130 DAT presented the effectiveness of organic manure on plant growth parameters of chilli pepper (Figures 1-3). However, the application of organic manure at the $2 \times$ rate significantly increased plant growth attributes, with a slight decrease observed at the $1 \times$ rate in all environment conditions.

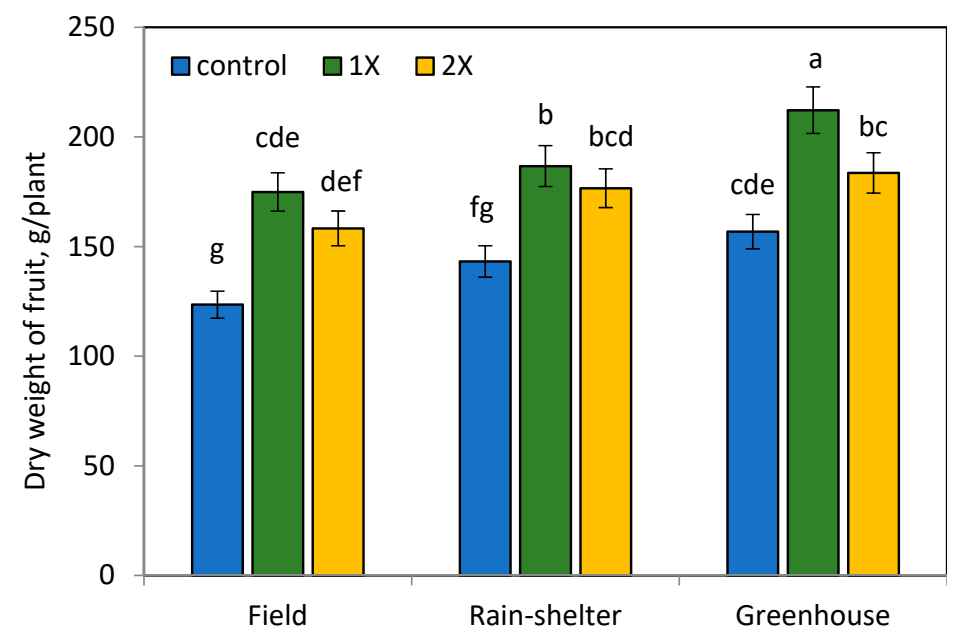

Figure 1. Dry weight of fruit per plant (g) at 130 DAT. Means separated by same lower case letter in each column are not significantly different at $p<0.05$ among treatments.

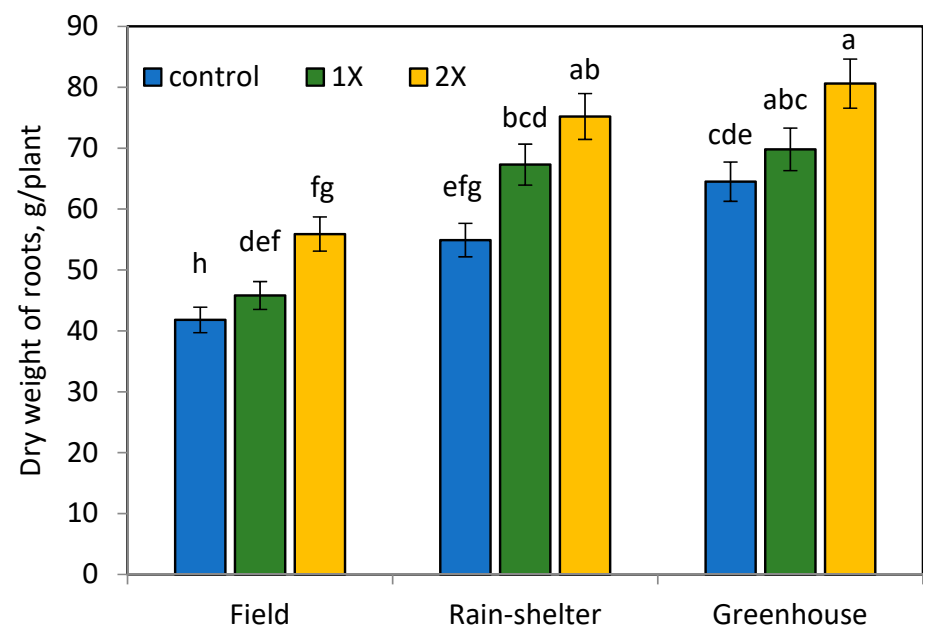

Figure 2. Dry weight of root weight per plant (g) at 130 DAT. Means separated by same lower case letter in each column are not significantly different at $p<0.05$ among treatments. LSD $=$ least significant difference. 


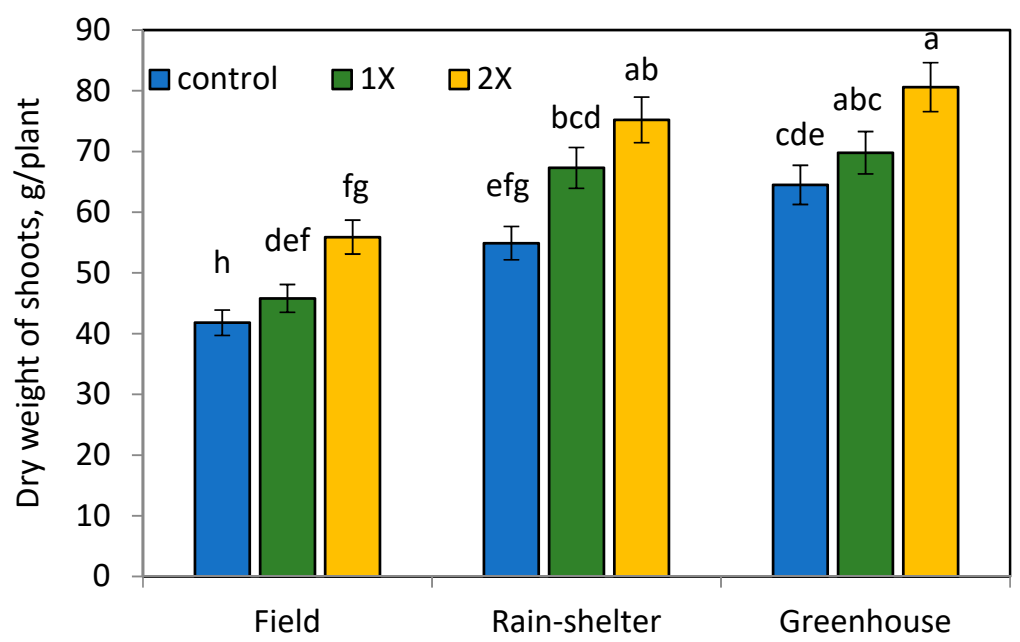

Figure 3. Dry weight of shoot weight per plant (g) at 130 DAT. Means separated by same lower case letter in each column are not significantly different at $p<0.05$ among treatments.

The enhanced plant development in response to organic manure application is well-known [24], exhibiting a significant steady increase in plant growth due to the improved nutrient conditions in the root rhizosphere. Although organic manure application did not bring any significant difference at the beginning of growing season, the growth parameters were significantly higher at both rates of organic manure treatment at 130 DAT (Table 4). The application of organic manure at the $1 \times$ and $2 \times$ rates significantly increased chilli pepper growth and $\mathrm{N}$ uptake, but the $1 \times$ rate treatment stabilized the biomass ratio $x$ plant yield interrelations. However, the organic manure based nutrient management scheme efficiently increased plant growth in all combinations of elevated temperature.

Table 4. Plant growth attributes at 130 DAT.

\begin{tabular}{lcccccc}
\hline Main Plot & Treatments & Height (cm) & Chlorophyll & $\begin{array}{c}\text { Length of } \\
\text { Internode } \mathbf{( c m})\end{array}$ & $\begin{array}{c}\text { Stem Diameter } \\
(\mathbf{m m})\end{array}$ & $\begin{array}{c}\text { Branch } \\
\mathbf{( N o} \text { ) }\end{array}$ \\
\hline \multirow{2}{*}{ Field } & control & $88.3 \mathrm{f}$ & $67.8 \mathrm{a}$ & $7.3 \mathrm{~b}$ & $13.3 \mathrm{f}$ & $26.7 \mathrm{~d}$ \\
& $\mathrm{X} 1$ & $95.0 \mathrm{f}$ & $73.1 \mathrm{a}$ & $8.7 \mathrm{ab}$ & $14.9 \mathrm{ef}$ & $28.0 \mathrm{~d}$ \\
& $\mathrm{X} 2$ & $98.7 \mathrm{f}$ & $77.3 \mathrm{a}$ & $9.0 \mathrm{ab}$ & $15.7 \mathrm{de}$ & $33.7 \mathrm{~cd}$ \\
\hline \multirow{2}{*}{ Rain-shelter } & Control & $113.0 \mathrm{de}$ & $69.6 \mathrm{a}$ & $9.7 \mathrm{ab}$ & $14.9 \mathrm{ef}$ & $29.3 \mathrm{~cd}$ \\
house & $\mathrm{X} 1$ & $116.3 \mathrm{~cd}$ & $71.7 \mathrm{a}$ & $10.0 \mathrm{ab}$ & $16.7 \mathrm{bc}$ & $35.7 \mathrm{bc}$ \\
& $\mathrm{X} 2$ & $117.7 \mathrm{bc}$ & $71.2 \mathrm{a}$ & $10.3 \mathrm{ab}$ & $16.1 \mathrm{~cd}$ & $35.7 \mathrm{bc}$ \\
\hline \multirow{3}{*}{ Green house } & Control & $110.7 \mathrm{de}$ & $69.3 \mathrm{a}$ & $9.7 \mathrm{ab}$ & $14.7 \mathrm{ef}$ & 31.0 \\
& $\mathrm{X} 1$ & $121.3 \mathrm{ab}$ & $73.9 \mathrm{a}$ & $10.3 \mathrm{ab}$ & $17.2 \mathrm{ab}$ & $39.0 \mathrm{ab}$ \\
\hline LSD 0.05 & & $126.0 \mathrm{a}$ & $74.6 \mathrm{a}$ & $11.7 \mathrm{a}$ & $17.6 \mathrm{a}$ & $42.7 \mathrm{a}$ \\
CV (\%) & & 11.6 & 6.47 & 2.92 & 1.85 & 8.62 \\
\hline
\end{tabular}

Means separated by same lower case letter in each column are not significantly different at $p<0.05$ among treatments. LSD = least significant difference.

\subsection{Effects of Organic Manure and Elevated Temperature on Dry Weight and Yield of Chilli Pepper}

The highest average of dry weight chilli pepper fruit yield was found at the $1 \times$ rate of organic manure application, especially under the greenhouse condition (Figures 1-3). Our results show that the dried fruit of chilli pepper at the $1 \times$ rate organic manure application was significantly higher by $78.9 \%$ in the greenhouse and $20.5 \%$ in the rain-shelter house compared to the field condition. Chilli peppers grown in the rain-shelter house at the $2 \times$ rate of organic manure treatment showed the highest increase by $24.5 \%, 34.5 \%$, and $13.5 \%$ of root, shoot, and fruit weight attributes, respectively, when compared to the appropriate control in the field. Likewise, root, shoot, and leaf dry weights at the 
$2 \times$ organic manure application in the greenhouse increased by $43.5 \%, 44.2 \%$, and $36.0 \%$, respectively compared to those of the control values.

However, the highest chilli peppers' yield was observed at the $1 \times$ rate of organic manure application under the greenhouse and followed by rain-shelter house conditions (Figure 3), the nutrient content in the soil probably was enough to meet the requirement of stabilizing crop growth. $\mathrm{N}$ sources positively influence crop productivity. However, a higher $\mathrm{N}$ input is accompanied by adverse effects for crop yield, soil health, and greenhouse gas emissions [25]. The quantity and quality of organic manure have tremendous effect on $\mathrm{N}$ balance of the soil, while other abiotic and biotic factors need to be considered to maintain $\mathrm{N}$ efficiency [26]. These results suggest that organic manure application at the $1 \times$ rate was sufficient to achieve the maximum chilli pepper yield in the greenhouse followed by the rain-shelter house, compared in the field (Figure 3). The increased temperature in the greenhouse affected the growth of chilli peppers and resulted in the highest yield at the $1 \times$ rate of organic manure application, suggesting that there is no need for extra organic manure application. The $2 \times$ rate organic manure application compared to the $1 \times$ rate caused a $31.3 \%$ and $5.8 \%$ reduction of fruit yield per plant in the greenhouse and rain-shelter house conditions, respectively. Significantly higher chilli pepper fruit yield harvested in the greenhouse gave a cue that the increased temperature synergistically optimized growth conditions and nutrient availability to produce a maximum chilli pepper yield at the $1 \times$ rate of organic manure treatment. The oversupply of organic manure to the soil led to an adverse effect for chilli pepper productivity and decreased its efficiency.

According to recent findings by Gu et al. [27], manure amendment can efficiently reduce ammonia volatilization in different cropping systems. On the other hand, a steady and significant increase in crop yield over the years with the application of organic manures was observed in many previous studies [10]. This might be explained by the fact that the organic manure application at the $2 \times$ rate resulted in higher $\mathrm{N}$ content in crop vegetative and generative organs than the $1 \times$ rate (Tables $5-8$ ). Furthermore, manure application at the $1 \times$ rate sustained a steady and smooth supply of $\mathrm{N}$ that might create favorable condition for plant growth and lead to higher $\mathrm{N}$ uptake from the soil. In addition, it is reasonable to predict that manure amendments reduce $\mathrm{N}$ loss, which might enhance $\mathrm{N}$ uptake.

Table 5. Root nutrient uptake at 130 DAT.

\begin{tabular}{|c|c|c|c|c|c|c|c|}
\hline \multirow{2}{*}{ Main Plot } & \multirow{2}{*}{ Treatments } & $\mathrm{Ca}$ & $\mathbf{K}$ & $\mathrm{Mg}$ & $\mathrm{Na}$ & $\mathbf{P}$ & $\mathbf{N}$ \\
\hline & & \multicolumn{6}{|c|}{$\left(\mathrm{mg} \mathrm{g}^{-1}\right)$} \\
\hline \multirow{3}{*}{ Field } & control & $11.3 \mathrm{~h}$ & $80.3 c$ & $9.4 \mathrm{~cd}$ & $3.6 \mathrm{~b}$ & $3.8 \mathrm{~d}$ & $46.6 \mathrm{~g}$ \\
\hline & $\mathrm{X} 1$ & $12.9 \mathrm{~g}$ & $114.9 \mathrm{ab}$ & $10.4 \mathrm{~cd}$ & $2.6 \mathrm{f}$ & $3.8 \mathrm{~d}$ & $51.4 \mathrm{f}$ \\
\hline & $\mathrm{X} 2$ & $16.2 \mathrm{c}$ & $119.8 \mathrm{ab}$ & $9.4 \mathrm{~cd}$ & $2.7 \mathrm{e}$ & $4.2 \mathrm{~b}$ & $52.8 \mathrm{~d}$ \\
\hline \multirow{3}{*}{ Rain-shelter house } & control & $15.2 \mathrm{e}$ & $67.2 c$ & $22.9 \mathrm{a}$ & $3.7 \mathrm{~b}$ & 2.9 & $36.9 \mathrm{i}$ \\
\hline & X1 & $15.5 \mathrm{~d}$ & $106.8 \mathrm{~b}$ & $15.7 \mathrm{~b}$ & $4.1 \mathrm{a}$ & $3.8 \mathrm{~d}$ & $44.5 \mathrm{~h}$ \\
\hline & $\mathrm{X} 2$ & $17.3 \mathrm{a}$ & $118.2 \mathrm{ab}$ & $11.4 \mathrm{c}$ & $3.7 \mathrm{~b}$ & $4.3 \mathrm{a}$ & $56.2 \mathrm{c}$ \\
\hline \multirow{3}{*}{ Green house } & control & $14.4 \mathrm{f}$ & $75.9 c$ & $20.9 \mathrm{ab}$ & $3.1 \mathrm{~d}$ & $3.3 \mathrm{e}$ & $34.2 \mathrm{j}$ \\
\hline & $\mathrm{X} 1$ & $15.4 \mathrm{~d}$ & $96.6 \mathrm{bc}$ & $15.8 \mathrm{~b}$ & $3.3 \mathrm{c}$ & $4.1 \mathrm{c}$ & $61.2 \mathrm{~b}$ \\
\hline & $\mathrm{X} 2$ & $16.9 \mathrm{~b}$ & 126.7 a & $15.8 \mathrm{~b}$ & $2.6 \mathrm{f}$ & $4.1 \mathrm{c}$ & $79.6 \mathrm{a}$ \\
\hline LSD 0.05 & & 2.3 & 10.4 & 4.9 & 1.3 & 0.5 & 0.6 \\
\hline CV $(\%)$ & & 10.4 & 13.7 & 13.2 & 8.1 & 8.5 & 8.1 \\
\hline
\end{tabular}

Means separated by same lower case letter in each column are not significantly different at $p<0.05$ among treatments.

Table 6. Shoot nutrient uptake at 130 DAT.

\begin{tabular}{lccccccc}
\hline \multirow{2}{*}{ Main Plot } & \multirow{2}{*}{ Treatments } & $\mathbf{C a}$ & $\mathbf{K}$ & $\mathbf{M g}$ & $\mathbf{N a}$ & $\mathbf{P}$ & $\mathbf{N}$ \\
\cline { 3 - 8 } & \multicolumn{7}{c}{$\mathbf{m g ~ g}^{-\mathbf{1}} \mathbf{)}$} \\
\hline \multirow{3}{*}{ Field } & control & $11.1 \mathrm{~d}$ & $129.9 \mathrm{e}$ & $6.1 \mathrm{~cd}$ & $0.60 \mathrm{bc}$ & $3.68 \mathrm{~d}$ & $44.5 \mathrm{~d}$ \\
& $\mathrm{X} 1$ & $14.4 \mathrm{c}$ & $134.6 \mathrm{~cd}$ & $7.4 \mathrm{c}$ & $0.57 \mathrm{bc}$ & $3.78 \mathrm{~cd}$ & $49.9 \mathrm{~cd}$ \\
& $\mathrm{X} 2$ & $25.2 \mathrm{ab}$ & $137.9 \mathrm{~cd}$ & $8.7 \mathrm{ab}$ & $0.66 \mathrm{~b}$ & $4.01 \mathrm{bc}$ & $50.1 \mathrm{c}$ \\
\hline
\end{tabular}


Table 6. Cont.

\begin{tabular}{|c|c|c|c|c|c|c|c|}
\hline \multirow{2}{*}{ Main Plot } & \multirow{2}{*}{ Treatments } & $\mathrm{Ca}$ & $\mathbf{K}$ & Mg & $\mathrm{Na}$ & $\mathbf{P}$ & $\mathbf{N}$ \\
\hline & & \multicolumn{6}{|c|}{$\left(\mathrm{mg} \mathrm{g}^{-1}\right)$} \\
\hline \multirow{3}{*}{ Rain-shelter house } & control & $18.5 \mathrm{bc}$ & $166.3 \mathrm{bc}$ & $9.5 \mathrm{ab}$ & $0.65 \mathrm{~b}$ & $3.93 c$ & $44.0 \mathrm{e}$ \\
\hline & $\mathrm{X} 1$ & $25.8 \mathrm{ab}$ & $176.3 \mathrm{~b}$ & $6.7 \mathrm{bc}$ & $0.68 \mathrm{ab}$ & $4.12 \mathrm{~b}$ & $49.7 \mathrm{~cd}$ \\
\hline & $\mathrm{X} 2$ & $27.3 \mathrm{a}$ & $166.3 \mathrm{bc}$ & $6.9 \mathrm{bc}$ & $0.78 \mathrm{a}$ & $4.04 \mathrm{bc}$ & $50.2 \mathrm{~b}$ \\
\hline \multirow{3}{*}{ Green house } & control & $20.8 \mathrm{~b}$ & $155.3 \mathrm{c}$ & $7.7 \mathrm{~b}$ & $0.68 \mathrm{ab}$ & $4.04 \mathrm{bc}$ & $40.3 \mathrm{f}$ \\
\hline & $\mathrm{X} 1$ & $24.3 \mathrm{ab}$ & $174.1 \mathrm{~b}$ & $8.1 \mathrm{ab}$ & $0.70 \mathrm{ab}$ & $4.42 \mathrm{ab}$ & $51.7 \mathrm{bc}$ \\
\hline & $\mathrm{X} 2$ & $27.7 \mathrm{a}$ & $219.2 \mathrm{a}$ & $10.2 \mathrm{a}$ & $0.81 \mathrm{a}$ & $4.49 \mathrm{a}$ & $54.0 \mathrm{a}$ \\
\hline LSD 0.05 & & 3.8 & 29.8 & 2.48 & 0.16 & 0.29 & 0.57 \\
\hline CV (\%) & & 11.9 & 12.6 & 9.6 & 6.3 & 4.9 & 8.1 \\
\hline
\end{tabular}

Means separated by same lower case letter in each column are not significantly different at $p<0.05$ among treatments.

Table 7. Fruit nutrient uptake at 130 DAT.

\begin{tabular}{|c|c|c|c|c|c|c|c|}
\hline \multirow{2}{*}{ Main Plot } & \multirow{2}{*}{ Treatments } & $\mathrm{Ca}$ & $\mathbf{K}$ & Mg & $\mathrm{Na}$ & $\mathbf{P}$ & $\mathbf{N}$ \\
\hline & & \multicolumn{6}{|c|}{$\left(\mathrm{mg} \mathrm{g}^{-1}\right)$} \\
\hline \multirow{3}{*}{ Field } & control & $2.0 \mathrm{f}$ & $26.5 \mathrm{bc}$ & $1.7 \mathrm{e}$ & $1.5 \mathrm{~b}$ & $3.8 \mathrm{~g}$ & $22.0 \mathrm{f}$ \\
\hline & X1 & $2.7 \mathrm{~d}$ & $31.8 \mathrm{bc}$ & $2.3 \mathrm{c}$ & $1.8 \mathrm{a}$ & $4.2 \mathrm{~d}$ & $27.0 \mathrm{c}$ \\
\hline & $\mathrm{X} 2$ & $2.9 \mathrm{c}$ & $34.6 \mathrm{ab}$ & $2.5 \mathrm{~b}$ & $1.8 \mathrm{a}$ & $4.3 \mathrm{c}$ & $27.9 \mathrm{~b}$ \\
\hline \multirow{3}{*}{ Rain-shelter house } & control & $2.0 \mathrm{f}$ & $26.9 \mathrm{bc}$ & $1.7 \mathrm{e}$ & $1.2 \mathrm{~d}$ & $3.9 \mathrm{f}$ & $23.5 \mathrm{e}$ \\
\hline & $\mathrm{X} 1$ & $2.7 \mathrm{~d}$ & $33.5 \mathrm{ab}$ & $2.7 \mathrm{a}$ & $1.5 \mathrm{~b}$ & $3.7 \mathrm{~h}$ & $27.9 \mathrm{~b}$ \\
\hline & $\mathrm{X} 2$ & $3.2 \mathrm{a}$ & $36.9 \mathrm{ab}$ & $2.3 \mathrm{c}$ & $1.5 \mathrm{~b}$ & $4.4 \mathrm{~b}$ & $26.0 \mathrm{~d}$ \\
\hline \multirow{3}{*}{ Green house } & control & $2.1 \mathrm{e}$ & $27.1 \mathrm{bc}$ & $1.6 \mathrm{f}$ & $0.9 \mathrm{e}$ & $4.0 \mathrm{e}$ & $21.2 \mathrm{~g}$ \\
\hline & $\mathrm{X} 1$ & $3.1 \mathrm{~b}$ & $32.2 \mathrm{~b}$ & $2.1 \mathrm{~d}$ & $1.4 \mathrm{c}$ & $4.2 \mathrm{~d}$ & $27.1 \mathrm{c}$ \\
\hline & $\mathrm{X} 2$ & $3.2 \mathrm{a}$ & $38.8 \mathrm{a}$ & $2.7 \mathrm{a}$ & $1.4 \mathrm{c}$ & $4.5 \mathrm{a}$ & $30.4 \mathrm{a}$ \\
\hline LSD 0.05 & & 0.43 & 6.1 & 0.4 & 0.4 & 0.8 & 0.5 \\
\hline $\mathrm{CV}(\%)$ & & 11.2 & 13.1 & 12.9 & 10.7 & 13.1 & 13.3 \\
\hline
\end{tabular}

Means separated by same lower case letter in each column are not significantly different at $p<0.05$ among treatments.

Table 8. Leaf nutrient uptake at 130 DAT.

\begin{tabular}{|c|c|c|c|c|c|c|c|}
\hline \multirow{2}{*}{$\begin{array}{l}\text { Main } \\
\text { Plot }\end{array}$} & \multirow{2}{*}{ Treatments } & $\mathrm{Ca}$ & $\mathbf{K}$ & Mg & $\mathrm{Na}$ & $\mathbf{P}$ & $\mathbf{N}$ \\
\hline & & \multicolumn{6}{|c|}{$\left(\mathrm{mg} \mathrm{g}^{-1}\right)$} \\
\hline \multirow{3}{*}{ Field } & control & $28.9 \mathrm{~d}$ & $120.1 \mathrm{~d}$ & $12.2 \mathrm{~d}$ & $0.66 \mathrm{~b}$ & $5.1 \mathrm{~d}$ & $58.2 \mathrm{~d}$ \\
\hline & $\mathrm{X} 1$ & $49.3 \mathrm{bc}$ & $182.5 \mathrm{~b}$ & $15.3 \mathrm{bc}$ & $0.59 \mathrm{c}$ & $6.7 \mathrm{~b}$ & $78.6 \mathrm{c}$ \\
\hline & $\mathrm{X} 2$ & $50.8 \mathrm{~b}$ & $221.4 \mathrm{a}$ & $15.9 \mathrm{~b}$ & $0.57 \mathrm{c}$ & $7.9 \mathrm{a}$ & $84.0 \mathrm{a}$ \\
\hline \multirow{3}{*}{$\begin{array}{l}\text { Rain-sh } \\
\text { house }\end{array}$} & control & $39.3 \mathrm{c}$ & $166.2 \mathrm{bc}$ & $14.7 \mathrm{c}$ & $0.65 \mathrm{~b}$ & $5.2 \mathrm{~d}$ & $55.5 \mathrm{e}$ \\
\hline & heltef 1 & $59.8 \mathrm{ab}$ & $240.5 \mathrm{a}$ & $17.2 \mathrm{a}$ & $0.77 \mathrm{a}$ & $6.7 b$ & $81.6 \mathrm{~b}$ \\
\hline & $\mathrm{X} 2$ & $67.5 \mathrm{a}$ & $243.2 \mathrm{a}$ & $17.1 \mathrm{a}$ & $0.75 \mathrm{a}$ & $7.5 \mathrm{ab}$ & $79.0 \mathrm{c}$ \\
\hline \multirow{3}{*}{$\begin{array}{l}\text { Green } \\
\text { house }\end{array}$} & control & $49.5 \mathrm{bc}$ & $142.6 \mathrm{c}$ & $15.0 \mathrm{c}$ & $0.73 \mathrm{a}$ & $5.3 \mathrm{~d}$ & $53.2 \mathrm{f}$ \\
\hline & $\mathrm{X} 1$ & $66.2 \mathrm{a}$ & $183.6 \mathrm{~b}$ & $17.6 \mathrm{a}$ & $0.77 \mathrm{a}$ & $6.1 \mathrm{c}$ & $78.4 \mathrm{c}$ \\
\hline & $\mathrm{X} 2$ & $67.5 \mathrm{a}$ & $243.2 \mathrm{a}$ & $17.4 \mathrm{a}$ & $0.75 a$ & $7.5 \mathrm{ab}$ & $79.0 \mathrm{c}$ \\
\hline \multirow{2}{*}{\multicolumn{2}{|c|}{$\begin{array}{l}\text { LSD } 0.05 \\
\text { CV (\%) }\end{array}$}} & 11.8 & 41.1 & 1.1 & 0.12 & 0.5 & 0.66 \\
\hline & & 15.4 & 15.0 & 4.9 & 15.3 & 5.2 & 6.2 \\
\hline
\end{tabular}

Means separated by same lower case letter in each column are not significantly different at $p<0.05$ among treatments.

\subsection{Effects of Organic Manure and Temperature on the Nutrition of Chilli Peppers}

The application of organic manure increased plant $\mathrm{Ca}, \mathrm{K}, \mathrm{Mg}, \mathrm{Na}$, total $\mathrm{P}$, and $\mathrm{N}$ contents at all temperature environments, especially in the greenhouse condition with significant differences (Tables 5-8). In the roots, the highest nutrient uptake was observed at the $2 \times$ rate of organic manure 
application in all three temperature conditions. However, the nutrient content in the plant roots was more pronounced in the greenhouse condition (Table 5). Ca, $\mathrm{K}$, and $\mathrm{Mg}$ contents increased by $49.8 \%$, $57.8 \%$, and $68.6 \%$, respectively, in the greenhouse condition compared to the respective control in the field condition, while $\mathrm{Na}$ and $\mathrm{P}$ concentrations were slightly higher in the chilli roots grown under the rain-shelter house condition.

The organic manure application increased nutrient uptake into the roots, thereby nutrient content of the shoots increased (Table 6). $\mathrm{Ca}, \mathrm{K}$, and $\mathrm{Mg}$ contents of chilli pepper grown at the $2 \times$ rate organic manure treatment in the greenhouse condition were higher by $10 \%, 58.9 \%$, and $17.6 \%$ compared to the respective control in the field condition. Similarly, $\mathrm{Na}$, total $\mathrm{P}$, and $\mathrm{N}$ contents at the $2 \times$ rate of organic manure application were higher by $23.8 \%, 11.8 \%$, and $7.8 \%$, respectively, compared to their respective control.

A similar trend of increasing nutrient contents by the $2 \times$ rate application of organic manure was also detected in the fruit content (Table 7). The increased temperature effect comparing the two rates of organic manure application was significant, suggesting that higher temperature and organic manure application generate greater nutrient content in chilli pepper fruits. Averaged across, organic manure application as a subplot significantly increased total $\mathrm{Ca}, \mathrm{K}$, and $\mathrm{Mg}$ contents by $11.2 \%, 12.1 \%$, and $8.7 \%$, respectively, compared to the respective control. A similar trend was observed on total $\mathrm{P}$ and $\mathrm{N}$ contents in chilli pepper fruits. However, Na content was slightly higher at the $1 \times$ rate organic manure application in the greenhouse condition.

Analyses of leaf chemical content of chilli pepper exhibited a similar trend to the increase of nutrient levels depending on the organic manure application (Table 8). The applied organic manure and elevated air temperature interactions promoted nutrient uptake by chilli peppers, which resulted in increased plant biomass and yield parameters. As expected, organic manure application initially improved soil properties and promoted plant growth, which resulted in the increase of plant nutrient uptake, growth, and yield [27]. The application of organic manure and elevated temperature interaction resulted in the abundance of nutrients in the soil, probably associated with the impact of beneficial microbes and favorable conditions for plant growth. These results indicate that organic manure application can alter mineral nutrient profiles in all plant parts, and improve their uptake and mobility within plants.

\subsection{Effects of Different Rates of Organic Manure Application on the Soil's Chemical Contents}

The application of organic manure significantly increased soil organic matter $(\mathrm{OM})$ and nutrients content in all experimental plots (Tables 9 and 10). Averaged across soil depths, organic manure application, especially at the $2 \times$ rate, significantly increased soil OM content. At the end of the growing season, the highest $\mathrm{OM}$ content was observed in the field condition $\left(38.5 \mathrm{mg} \mathrm{kg}^{-1}\right)$ followed by greenhouse $\left(37.6 \mathrm{mg} \mathrm{kg}^{-1}\right)$, and rain-shelter house $\left(31.5 \mathrm{mg} \mathrm{kg}^{-1}\right)$ conditions at the $2 \times$ rate of organic manure treatments. Soil $\mathrm{pH}$ levels tended to decrease in the field and rain shelter house conditions at the end of the growing season, but slightly increased in the greenhouse condition in all organic manure treatments. The soil's EC parameter increased in the field condition, but the decrease was observed under the rain-shelter house and greenhouse conditions. Although no significant difference was observed in soil $\mathrm{K}$ and $\mathrm{Na}$ contents among treatments, some increase was noticed depending on the organic manure application rate, especially in the greenhouse condition. Furthermore, Ca and $\mathrm{Mg}$ contents of the soil increased with the increase in organic manure application rate, but it was statistically not significant in most cases.

In the control, $\mathrm{OM}$ and $\mathrm{N}$ contents slightly decreased at the end of growing season in all temperature conditions. In the case of no organic manure input to the soil, plants uptake available nutrients from the soil and decrease the content of these essential elements. The highest $\mathrm{N}$ content in the soil was determined with the highest application rate of organic manure. However, the increasing rates of $\mathrm{N}$ in the soil did not exert any significant effects on the concentrations of $\mathrm{K}$ and $\mathrm{Na}$, whereas consistently increased $\mathrm{Ca}$ and $\mathrm{Mg}$ contents. The increase of pepper plant nutrients content and yield was in response 
to the highly availability of organic nutrients in the soil after organic manure application. Temperature is also known to have a positive effect on the mineralization of soil OM and residues that may have affected nutrient availability in the elevated temperature under greenhouse condition.

It is well documented that higher $\mathrm{N}$ fertilization is usually accompanied with increased demand for other macro and micronutrients uptake by plants to maintain a balance. This phenomenon accelerates plant growth and yield formation processes in crops.

Table 9. Effects of different rates of organic manure application on soil chemical contents at the end of the experiment.

\begin{tabular}{lcccccc}
\hline Main Plot & Treatments & pH (1 : 5) & E.C (dS/m) & OM (g/kg) & $\begin{array}{c}\mathbf{N O}_{3}-\mathbf{N} \\
\text { (ppm) }\end{array}$ & $\begin{array}{c}\mathbf{N H}_{\mathbf{4}}{ }^{+}-\mathbf{N} \\
\text { (ppm) }\end{array}$ \\
\hline \multirow{3}{*}{ Field } & Control & $5.8 \mathrm{c}$ & $1.2 \mathrm{~b}$ & $32.4 \mathrm{~b}$ & $10.7 \mathrm{f}$ & $3.1 \mathrm{de}$ \\
& $\mathrm{X} 1$ & $6.1 \mathrm{~b}$ & $1.1 \mathrm{~b}$ & $37.7 \mathrm{a}$ & $21.0 \mathrm{~d}$ & $7.7 \mathrm{c}$ \\
& $\mathrm{X} 2$ & $6.5 \mathrm{ab}$ & $0.7 \mathrm{c}$ & $38.5 \mathrm{a}$ & $21.5 \mathrm{~d}$ & $1.6 \mathrm{e}$ \\
\hline \multirow{2}{*}{ Rain-shelter } & Control & $6.3 \mathrm{~b}$ & $1.4 \mathrm{ab}$ & $28.6 \mathrm{c}$ & $69.0 \mathrm{a}$ & $22.7 \mathrm{~b}$ \\
house & $\mathrm{X} 1$ & $6.4 \mathrm{ab}$ & $1.5 \mathrm{a}$ & $31.9 \mathrm{~b}$ & $51.1 \mathrm{~b}$ & $23.6 \mathrm{~b}$ \\
& $\mathrm{X} 2$ & $6.8 \mathrm{a}$ & $1.4 \mathrm{ab}$ & $31.5 \mathrm{~b}$ & $22.4 \mathrm{~d}$ & $40.7 \mathrm{a}$ \\
\hline \multirow{2}{*}{ Green-house } & Control & $5.9 \mathrm{bc}$ & $0.8 \mathrm{c}$ & $25.6 \mathrm{c}$ & $35.8 \mathrm{c}$ & $5.7 \mathrm{~cd}$ \\
& $\mathrm{X} 1$ & $6.3 \mathrm{~b}$ & $1.1 \mathrm{~b}$ & $31.6 \mathrm{~b}$ & $19.7 \mathrm{de}$ & $4.0 \mathrm{~cd}$ \\
\hline LSD 0.05 & & $6.5 \mathrm{ab}$ & $1.5 \mathrm{a}$ & $37.6 \mathrm{a}$ & $17.7 \mathrm{de}$ & $7.0 \mathrm{c}$ \\
CV (\%) & & 4.5 & 0.3 & 4.6 & 8.4 & 4.6 \\
\hline
\end{tabular}

Means separated by same lower case letter in each column are not significantly different at $p<0.05$ among treatments.

Table 10. Effects of different rates of organic manure application on soil chemical contents at the end of the experiment.

\begin{tabular}{|c|c|c|c|c|c|c|}
\hline Main Plot & Treatments & $\begin{array}{c}\mathrm{P}_{2} \mathrm{O}_{5} \\
(\mathrm{mg} / \mathrm{kg})\end{array}$ & $\mathrm{K},(\mathrm{cmol} / \mathrm{kg})$ & $\begin{array}{c}\mathrm{Ca}, \\
\text { (cmol/kg) }\end{array}$ & $\begin{array}{c}\mathrm{Mg}, \\
\text { (cmol/kg) }\end{array}$ & $\begin{array}{c}\mathrm{Na}, \\
\text { (cmol/kg) }\end{array}$ \\
\hline \multirow{3}{*}{ Field } & control & $374.7 \mathrm{i}$ & $1.2 \mathrm{c}$ & $7.2 \mathrm{f}$ & $1.9 \mathrm{~d}$ & $0.1 \mathrm{c}$ \\
\hline & X1 & $480.6 \mathrm{~g}$ & $1.2 \mathrm{c}$ & $7.8 \mathrm{~d}$ & $2.5 \mathrm{~b}$ & $0.1 \mathrm{c}$ \\
\hline & $\mathrm{X} 2$ & $542.1 \mathrm{f}$ & $1.3 \mathrm{bc}$ & $7.8 \mathrm{~d}$ & $2.5 \mathrm{~b}$ & $0.1 \mathrm{c}$ \\
\hline \multirow{3}{*}{$\begin{array}{l}\text { Rain-shelter } \\
\text { house }\end{array}$} & control & $412.3 \mathrm{~h}$ & $1.3 \mathrm{bc}$ & $8.3 \mathrm{c}$ & $2.3 \mathrm{bc}$ & $0.2 \mathrm{~b}$ \\
\hline & X1 & $569.9 \mathrm{e}$ & $1.3 \mathrm{bc}$ & $8.7 \mathrm{~b}$ & $2.3 \mathrm{bc}$ & $0.2 \mathrm{~b}$ \\
\hline & $\mathrm{X} 2$ & $588.0 \mathrm{~d}$ & $1.2 \mathrm{c}$ & $8.8 \mathrm{a}$ & $2.4 \mathrm{bc}$ & $0.3 \mathrm{a}$ \\
\hline \multirow{3}{*}{ Green-house } & control & $727.6 \mathrm{c}$ & $1.3 \mathrm{bc}$ & $7.6 \mathrm{e}$ & $2.5 \mathrm{~b}$ & $0.1 \mathrm{c}$ \\
\hline & X1 & $772.9 \mathrm{~b}$ & $1.4 \mathrm{~b}$ & $8.7 \mathrm{~b}$ & $2.6 \mathrm{ab}$ & $0.2 \mathrm{~b}$ \\
\hline & $\mathrm{X} 2$ & $862.8 \mathrm{a}$ & $1.9 \mathrm{a}$ & $8.8 \mathrm{a}$ & $3.0 \mathrm{a}$ & $0.2 \mathrm{~b}$ \\
\hline LSD 0.05 & & 13.4 & 1.5 & 0.95 & 0.5 & 0.09 \\
\hline CV (\%) & & 6.5 & 6.3 & 7.4 & 9.7 & 5.6 \\
\hline
\end{tabular}

Means separated by same lower case letter in each column are not significantly different at $p<0.05$ among treatments.

\section{Discussion}

Theoretically, incorporating organic manure in soil should improve the growth attributes of plants. However, in this study we demonstrate that an optimum amount of organic manure is advantageous for higher yields. Furthermore, elevated temperatures substantially improved chilli pepper fruit yield in the greenhouse and rain-shelter house conditions. Likewise, plant growth parameters such as the dry weight of leaf, shoot, and root tended to be higher in the greenhouse followed by rain-shelter plastic house compared to the field conditions. Favorable elevated temperature conditions were the reason for the intensive plant growth in the greenhouse, although several authors have declared the negative impact of elevated temperatures on crop productivity [6,28]. However, it is essential to consider the crop's biological properties and soil-climatic conditions. Chilli peppers originated in 
Mexico, therefore, this plant prefers high temperatures by its biological properties, and the elevated temperature in the greenhouse may have promoted metabolic processes in the plant cells. Therefore, higher accumulated temperatures of $3091{ }^{\circ} \mathrm{C}$ and $3168{ }^{\circ} \mathrm{C}$ in the rain-shelter plastic house and plastic greenhouse, respectively, were more effective compared to the lower temperature $\left(2944^{\circ} \mathrm{C}\right)$ in the field (Table 1). Similarly, air and soil temperatures were higher under greenhouse followed by rain-shelter plastic conditions than those in the field condition (Table 1). The accumulated heat from sunlight maintained daily $2-3{ }^{\circ} \mathrm{C}$ higher temperature in the greenhouse and rain shelter house during the entire period of the experiment. The elevated air temperature in the greenhouse triggers an increase in soil temperature. This implies that mineralization processes of the applied organic manures in the greenhouse may have been faster than at other ambient conditions.

In the field, the fruit yield did not differ substantially at the $1 \times$ and $2 \times$ rates of organic manure treatments with values of 179.4 and $158.3 \mathrm{~g} \mathrm{plant}^{-1}$ at $130 \mathrm{DAT}$, respectively, with a significant difference compared to the control treatment $\left(123.5 \mathrm{~g} \mathrm{plant}^{-1}\right)$. On the other hand, these values in the greenhouse condition were substantially higher, recorded 212.2 and $183.6 \mathrm{~g} \mathrm{plant}^{-1}$ at the $1 \times$ and $2 \times$ rates of organic manure treatments, respectively. These results show that organic manure along with elevated temperature integration were the main factors that might have stimulated plant growth and chilli pepper yield. The present study is in agreement with results by Guo et al. who reported that elevated temperatures have a positive effect on crop yield in the North China Plain [27].

The organically amended soil is generally reflected in the enhanced chemical content of the plant vegetative parts. The results indicate that the application of organic manure significantly enhances $\mathrm{Ca}, \mathrm{K}, \mathrm{Mg}$, Na, total $\mathrm{P}$, and $\mathrm{N}$ contents in all plant vegetative parts, which is reflected on the growth and yield attributes of chilli peppers. As a subplot effect in this study, an increment in plant growth features was in response to the improved soil quality by the input of organic manure as a fertility amendment. Recently, Surendran et al. reported that increased temperature and moisture cause rapid mineralization of soil organic carbon in tropical regions $[29,30]$. The results of this study also show that the highest soil moisture was observed in the field followed by greenhouse and rain shelter conditions.

Organic manure application improves soil physical-chemical properties by actively facilitating bacterial growth as well [31,32]. As reported by Gomiero et al., besides enhancing soil quality, organic farming can also improve water use efficiency and this can lead to an increase in yield by $70-90 \%$ [2]. In order to have a clear view of organic manure application, a long-term experiment must be conducted. For instance, the experiment conducted in Northeast of China showed that 18 years of manure improved maize yield by $218 \%$ when compared to the control value [33]. Furthermore, Diacono and Montemurro found that long-term application of organic amendments increased crop yield by up to $250 \%$ and improved crop yield quality [24]. Rational implementation of organic manure is accompanied by the highest productivity of agricultural crops and without environmental damage even under adverse climatic conditions [34,35].

\section{Conclusions}

The beneficial effect of organic manure associated with elevated temperatures was found to have high efficiency in improving chilli peppers' nutrient content and crop productivity. The application of $2 \times$ rate $\left(265.4 \mathrm{~kg} \mathrm{ha}^{-1}\right)$ organic manure substantially increased the growth parameters of chilli peppers at all temperature conditions, whereas the $1 \times$ rate $\left(132.7 \mathrm{~kg} \mathrm{ha}^{-1}\right)$ exhibited a higher yield increase, especially under elevated temperatures in the greenhouse conditions. Therefore, applying the $1 \times$ rate of organic manure is considered the optimum for obtaining a maximum chilli pepper fruit yield. The excessive use of ( $2 \times$ rate) organic manure may result in the accumulation of more vegetative biomass than the increase in chilli pepper yield value. Thus, the rational use of organic amendments for chilli pepper cultivation is highly recommended depending on soil quality and environmental conditions.

Further studies are required to understand the long-term effect of organic manure application on chilli pepper production under variable temperature conditions. Furthermore, it is important to develop a proper simulation model to elucidate the long-term effect of an elevated temperature environment and 
organic amendments on growth and yield of chilli peppers. Despite forecast uncertainties, the project model allows improving the efficiency of agricultural management practices in various surroundings.

Author Contributions: K.W.P., was the Principal Investigator of the project, initiated and supervised the experiment, and contributed intellectually to the development of the final manuscript; Y.L., conceived the original idea for the analysis and participated in the interpretation of the results; B.K., H.J.Y., and K.M.C., undertook the literature search and drafted the manuscript; F.R., T.H.L., M.U., and A.B.B., helped with experiments and participated in the interpretation of the results. All authors have read and approved the final paper.

Funding: This study was conducted by support from the "Cooperative Research Program for Agriculture Science \& Technology Development (Project No. PJ01283702)" Rural Development Administration, Republic of Korea.

Conflicts of Interest: The authors declare no conflict of interest.

\section{References}

1. Lobell, D.B.; Schlenker, W.; Costa-Roberts, J. Climate trends and global crop production since 1980. Science 2011, 333, 616-620. [CrossRef] [PubMed]

2. Gomiero, T.; Pimentel, D.; Paoletti, M.G. Environmental Impact of Different Agricultural Management Practices: Conventional vs. Org. Agric. Crit. Rev. Plant Sci. 2011, 30, 95-124. [CrossRef]

3. Meehl, G.A.; Stocker, T.F.; Collins, W.D.; Friedlingstein, P.; Gaye, T.; Gregory, J.M.; Kitoh, A.; Knutti, R.; Murphy, J.M.; Noda, A.; et al. Global climate projections. In Climate Change 2007, The Physicalscience Basis; Solomon, S., Qin, D., Manning, M., Chen, Z., Marquis, M., Averyt, K.B., Tignor, M., Miller, H.L., Eds.; Cambridge University Press: Cambridge, UK, 2007; pp. 283-296.

4. Challinor, A.J.; Watson, J.; Lobell, D.B.; Howden, S.M.; Smith, D.R.; Chhetri, N. A-meta-analysis of crop yield under climate change and adaptation. Nat. Clim. Chang. 2014, 4, 287-291. [CrossRef]

5. Graß, R.; Thies, B.; Kersebaum, K.C.; Wachendorf, M. Simulating dry matter yield of two cropping systems with the simulation model HERMES to evaluate impact of future climate change. Eur. J. Agron. 2015, 70, 1-10. [CrossRef]

6. Lotter, D.W.; Seidel, R.; Liebhardt, W. The performance of organic and conventional cropping systems in an extreme climate year. Am. J. Altern. Agric. 2003, 18, 146-154. [CrossRef]

7. Liang, S.; Li, Y.; Zhang, X.; Sun, Z.; Sun, N.; Duan, Y.; Xu, M.; Wu, L. Response of crop yield and nitrogen use efficiency for wheat-maize cropping system to future climate change in northern China. Agric. For. Meteorol. 2018, 262, 310-321. [CrossRef]

8. Dungan, R.S.; Gan, J.; Yates, S.R. Effect of temperature, organic amendment rate and moisture content on the degradation of 1,3-dichloropropene in soil. Pest Manag. Sci. 2001, 57, 1107-1113. [CrossRef] [PubMed]

9. Chludil, H.; Corbino, G.B.; Leicach, S.R. Soil quality effects on Chenopodium album flavonoid content and antioxidant potential. J. Agric. Food Chem. 2008, 56, 5050-5056. [CrossRef] [PubMed]

10. Parham, J.A.S.P.; Deng, S.; Raun, W.; Johnson, G. Long-term cattle manure application in soil. Biol. Fertil. Soils 2002, 35, 328-337.

11. Wang, W.J.; Zhu Dan, Y.; Wang, H.S. Effect of different amount of organic fertilizer in the yield of organic vegetables. North Hortic. 2010, 17, 29-30.

12. Nguyen, N.L.; Kim, Y.J.; Hoang, V.A.; Subramaniyam, S.; Kang, J.P.; Kang, C.H.; Yang, D.C. Bacterial Diversity and Community Structure in Korean Ginseng Field Soil Are Shifted by Cultivation Time. PLoS ONE 2016, 11, e0155055. [CrossRef] [PubMed]

13. Albiach, R.; Canet, R.; Pomares, F.; Ingelmo, F. Microbial biomass content andenzymatic activities after the application of organic amendments to a horticultural soil. Bioresour. Technol. 2000, 75, 43-48. [CrossRef]

14. Marin, A.; Ferreres, F.; Tomas-Barberan, F.A.; Gill, M.I. Characterization and quantification of antioxidant constituents of Sweet pepper (Capsicum annuum L.). J. Agric. Food Chem. 2004, 53, 3861-3869. [CrossRef] [PubMed]

15. Gangadhar, B.H.; Mishra, R.K.; Pandian, G.; Park, S.W. Comparative study of color, pungency, and biochemical composition in chili pepper (Capsicumannuum) under different light emitting diode treatments. Hortic. Sci. 2012, 47, 1729-1735.

16. Ren, H.; Endo, H.; Hayashi, T. The superiority of organically cultivated vegetables to ones regarding mutagenic activities. Mutat. Res. 2001, 496, 83-88. [CrossRef] 
17. Ibrahim, H.; Jaafar, M.; Karimi, H.Z.E.; Ghasemzadeh, E.A. Impact of organic and inorganic fertilizers application on the phytochemical and antioxidantactivity of Kacipfatimah (Labisia pumila Benth). Molecules 2013, 18, 10973-10988. [CrossRef]

18. DAT, S.; Teja, K.C.; Duary, B.; Agrawal, P.K.; Bhattacharya, S.S. Impact of nutrient management, soil type and location on the accumulation of capsaicin in Capsicum chinense (Jacq.): One of the hottest chili in the world. Sci. Hortic. 2016, 213, 354-366.

19. Statistics Korea. 2018. Available online: http://kostat.go.kr (accessed on 20 August 2019).

20. Dahal, K.; Knowles, V.L.; Plaxton, W.C.; Hüner, N.P.A. Enhancement of photosynthetic performance, water use efficiency and grain yield during long-term growth under increased $\mathrm{CO}_{2}$ in wheat and rye is growth temperature and cultivar dependent. Environ. Exp. Bot. 2014, 106, 207-220. [CrossRef]

21. NIAST. Method of Soil and Plant Analysis; National Institute of Agricultural Science and Technology: Suwon, Korea, 2000.

22. Chapman, H.D.; Pratt, F.P. Determination of Minerals by Titration Method: Methods of Analysis for Soils, Plants and Water; California University, Agriculture division: Oakland, CA, USA, 1982.

23. Cottenie, A.; Verloo, M.; Kiekens, L.; Velghe, G.; Camerlynck, R. Chemical Analysis of Plant and Soils; Laboratory of Analytical and Agrochemistry, State University of Ghent: Ghent, Belgium, 1982.

24. Diacono, M.; Montemurro, F. Long-term effects of organic amendments on soil fertility. In Sustainable Agriculture; Springer: Dordrecht, The Netherlands, 2011; Volume 2, pp. 761-786.

25. Fageria, N.K.; Baligar, V.C. Enhancing nitrogen use efficiency in crop plants. Adv. Agron. 2005, 88, 97-185.

26. Hati, K.M.; Swarup, A.; Mishra, B.; Manna, M.C.; Waniari, R.H.; Mandal, K.G.; Misra, A.K. Impact of long-term application of fertilizer, manure and lime under intensive cropping on physical properties and organic carbon content of an Alfisol. Geoderma 2008, 148, 173-179. [CrossRef]

27. Gu, L.; Liu, T.; Wang, J.; Liu, P.; Dong, S.; Zhao, B.; So, H.B.; Zhang, J.; Zhao, B.; Li, J. Lysimeter study of nitrogen losses and nitrogen use efficiency of Northern Chinese wheat. Field Crop. Res. 2016, 188, 82-95. [CrossRef]

28. Manna, M.C.; Swarup, A.; Wanjari, R.H.; Ravankar, H.N.; Mishra, B.; Saha, M.N.; Singh, Y.V.; Sahi, D.K.; Sarap, P.A. Long-term effect of fertilizer and manure application on soil organic carbon storage, soil quality and yield sustainability under sub-humid and semi-arid tropical India. Field Crop. Res. 2005, 93, 264-280. [CrossRef]

29. Surendran, U.; Vijayan, A.K.; Bujair, V.; Joseph, E.J. Influence of open and polyhouse conditions on soil carbon dioxide emission from Amaranthus plots with different nutrient management practices under changing climate scenario. Curr. Sci. 2018, 114, 1311-1317. [CrossRef]

30. Guo, R.; Lin, Z.; Mo, X.; Yang, C. Responses of crop yield and water use efficiency to climate change in the North China Plain. Agric. Water Manag. 2010, 97, 1185-1194. [CrossRef]

31. Wang, X.; Jia, Z.; Liang, L.; Yang, B.; Ding, R.; Nie, J.; Wang, J. Impacts of manure application on soil environment, rainfall use efficiency and crop biomass under dryland farming. Sci. Rep. 2016, 6, 20994. [CrossRef] [PubMed]

32. Weitza, A.; Linderb, E.; Frolkingc, S.; Crillc, P.; Kellerc, M. N2O emissions from humid tropical agricultural soils: Effects of soil moisture, texture and nitrogen availability. Soil Biol. Biochem. 2001, 33, 1077-1093. [CrossRef]

33. Zhang, X.Z.; Gao, H.J.; Peng, C.; Li, Q.; Zhu, P. Effects of combined application of organic manure and chemical fertilizer on maize yield and nitrogen utilization under equal nitrogen rates. J. Maize Sci. 2012, 20, 123-127.

34. Bai, Z.; Caspari, T.; Gonzalez, M.R.; Batjes, N.H.; Mäder, P.; Bünemann, E.K.; de Goede, R.; Brussaard, L.; Xu, M.; Ferreira, C.S.S.; et al. Effects of agricultural management practices on soil quality: A review of long-term experiments for Europe and China. Agric. Ecosyst. Environ. 2018, 265, 1-7. [CrossRef]

35. Bir, M.S.H.; Eom, M.Y.; Uddin, M.R.; Park, T.S.; Kang, H.W.; Park, K.W. Weed Population Dynamics under Climatic Change. Weed Turfgrass Sci. 2014, 3, 174-182. [CrossRef]

(C) 2019 by the authors. Licensee MDPI, Basel, Switzerland. This article is an open access article distributed under the terms and conditions of the Creative Commons Attribution (CC BY) license (http://creativecommons.org/licenses/by/4.0/). 